\title{
On the Ways of Creating Structural Irony in English Literary Discourse
}

\author{
Nalya Ovshieva \\ Department of germanic languages and literatures, the B.B. Gorodovikov Kalmyk State University, 358014, microdistrict 6, 1- \\ 71, Elista, Russia
}

\begin{abstract}
The concept of structural irony is traditionally associated with an implication of alternate or reversed meaning that pervades a work. A major technique for sustaining structural irony is the use of a naïve protagonist or unreliable narrator who continually interprets events and intentions in ways that the author signals are mistaken $[1,45]$.This paper sets out to investigate structural irony as the organizational principle in English literary discourse. After a survey of different views of structural irony, an attempt is made to verify that the pragmalinguistic techniques, viz. the play on double meaning, echoic mentioning of the word or phrase, the use of emphatic structures in free indirect speech, and repetition of patterns of behavior, are employed in constructing structural irony. The results of the analysis conducted on the material of short stories and novels of English-speaking authors will be presented in order to demonstrate that structural irony can be constructed by combining various linguistic devices to achieve the ironic effect.
\end{abstract}

Our paper deals with the issue of identifying the ways of creating structural irony in English literary discourse. This study seems relevant to an understanding of how structural irony is created since, being a mode of discourse, along with situational and dramatic ironies, it is still not sufficiently studied in the discursive aspect. The aim of the work is to identify the specifics of constructing structural irony in short stories and novels by English-speaking authors. The analysis of the linguistic material made it possible to identify the pragmalinguistic techniques of constructing structural irony, and namely the play on double meaning, echoic mentioning of the word or phrase, the use of emphatic structures in free indirect speech, and repetition of patterns of behavior.

The creation of irony involves a construction of contrariety based on norms and contexts that are partly individual and partly shared by interpretive communities [2]. Irony is, therefore, the linguistic form of dialectical thought because its use presupposes an awareness of the possible misuse of language [3]. "Structural irony refers to an implication of alternate or reversed meaning that pervades a work. A major technique for sustaining structural irony is the use of a naïve protagonist or unreliable narrator who continually interprets events and intentions in ways that the author signals are mistaken" [1]. In other words, structural irony is the use of a word or idea which possesses a double meaning. This double meaning is played upon in much of the text. It illustrates the naivety of the narrator or the hero in regards to their warped ideas about the world around them. The reader, on the other hand, understands the narrator or the hero to be unreliable, or naive.

According to D.H. Green [4], where the contrast is between the ironic statement and another context we are dealing with the specific category of structural irony. It can be detected in the romance informing the relationship between two characters or two scenes, and it is under these two headings that he conducted the investigation of structural irony.

Irony is, however, hard to pinpoint not only because it is by nature a form of disguise, but also because of its innate subjectivity. Consequently, by "irony" some critics do not mean a simple figure of speech or a linguistic trope, rather, a figure of (not necessarily always conscious) thought, a mode of perception, a deep recognition of the incongruities between appearance and reality [5]. Irony is essentially a mode of perception; its arena is that crucial space between the narrator and the narrative on the one hand, and on the other, between the narrative and the reader [6]. However, in the attitude of the narrator to his narrative, the presence of irony can be established with greater objectivity from the evidence of the text. Narrative stance therefore suggests itself as a suitable focus for investigation. The narrator's position vis-à-vis his narrative is indicative of his underlying stance; and the variations in that stance in turn reveal differing kinds and degrees of irony [6]. Traditionally the ironist has a dual vision, for he sees a latent reality divergent from the masking appearance on the surface. While recognizing the incongruities of the situation, he seems to accept things at their face value. Yet at the same time, by one means or another, he lets his other

Corresponding author: nalya154@mail.ru 
view shimmer through so that the reader too becomes aware of the alternative. In the reader's agreeing comprehension of the double meaning there is a tacit communication of the ironic perspective from the narrator to the reader [6]. Therefore, irony differs from other ways of communicating with double meanings such as metaphor and allegory in that it does not entirely eliminate the 'face value' meaning [7]. Even with complete sarcasm, which aims to give a meaning directly antithetical to the one presented, the original meaning cannot be discarded without losing the sense of irony. It is through comparing these two meanings that the degree or type of irony can be seen. Consequently, affect is a crucial part of irony, as different types of irony have different feelings or colors that are not experienced in its absence $[8,44]$. Affect might be part of what clues us in to the presence of irony.

In Linda Hutcheon's view, irony is something more than either a rhetorical trope or an outlook on life; it is a discursive strategy that is always engaged in the social and political [9]. The all-embracing character of structural irony is reflected in such terms as "leitmotif irony" [10], "associative irony" [11], "text-forming irony" [12], and "conceptual irony" [13]. We can draw parallels between structural, dramatic, and situational ironies in this respect. What structural and dramatic ironies have in common is that naïve protagonist speaks in ignorance of a situation or event known to the audience or to the other characters. But they are often differentiated by scale - dramatic irony happening in situations, and structural - pervading the entire scope. Structural irony, as a rule, culminates in situational irony. The point of difference between the two, however, is the same: structural irony runs through an entire work, whereas situational irony - only through the situation.

Having considered all the ways of constructing structural irony, I would like to illustrate them with the following examples from short stories and novels by English-speaking authors:

№ 1

He drew a long sigh of relief, and sat down again.

"Well?" she said.

Her voice had altered. It was slightly mocking defiant.

He answered her soberly and quietly.

"You are a very clever woman, Mrs. Merrowdene. I think you understand me. There must be no repetition. You know what I mean?"

"I know what you mean."

Her voice was even, devoid of expression. He nodded his head, satisfied. She was a clever woman, and she didn't want to be hanged.

Evans, a retired police inspector, recognizes a woman in his village whom he once suspected of murdering her husband. He is determined that her new husband will not suffer the same fate. Here the play on double meaning is created through different interpretation of the noun repetition: repetition of her crime vs repetition in the choice of the victim. As a matter of fact, Mrs Merrowdene avoids repetition in the choice of the victim: she kills the Inspector because he suspects her of a crime. The irony of the situation is that Evans is convinced that Mrs Merrowdene is going to kill her new husband, whereas she was actually intending to kill him.

№ 2

The aunt, in a dress of black lace over ivory colour, stood in the doorway. Her face was made up, but haggard with a look of unspeakable irritability, as if years of suppressed exasperation and dislike of her fellow-men had suddenly crumpled her into an old witch.

"Oh, aunt!" cried Cecilia.

"Why, mother, you're a little old lady!" came the astounded voice of Robert: like an astonished boy: as if it were a joke.

"Have you only just found it out?" snapped the old woman venomously.

"Yes! Why, I thought - " his voice tailed out in misgiving.

The haggard, old Pauline, in a frenzy of exasperation, said:

"Aren't we going down?"

Robert could not hide his surprise at the sight of his mother suddenly shriveled up into the haggard old woman she genuinely was. His exclamation 'you're a little old lady!' evokes associations with the key phrase of the story "the lovely lady" that she actually claimed to be. Hence, the exclamation seems ironic in another context, creating the play on double meaning through the antithesis: the lovely lady vs a little old lady.

№ 3

Robert and Cecilia fetched furtive glances at her. And Ciss, watching Robert, saw that he was so astonished and repelled by his mother's looks, that he was another man.

"What kind of a drive home did you have?" snapped Pauline, with an almost gibbering irritability.

"It rained, of course," he said.

"How clever of you to have found that out!" said his mother, with the grisly grin of malice that had succeeded her arch smirk.

"I don't understand," he said with quiet suavity.

"It's apparent," said his mother, rapidly and sloppily eating her food.

When Robert sees the transformation in his mother's demeanour, it works a transformation in him, too, and he suddenly seems "another man". Pauline, having lost all her famous willpower, cannot help nagging Robert about his being dull. Her ironic retort 'How clever of you to have found that out!' evokes associations with her sharp retort in the previous fragment of conversation 'Have you only just found it out?', whereas, in fact, it is now that Robert is becoming aware of her energy vampirism, her gaining youth while draining the life from him.

№ 4

To the old lady's nephew, Charles Ridgeway, the doctor was slightly more explicit.

"Do not misunderstand me," he said. "Your aunt may live for years, probably will. At the same time, shock or overexertion might carry her off like that!" He snapped 
his fingers. "She must lead a very quiet life. No exertion. No fatigue. But, of course, she must not be allowed to brood. She must be kept cheerful and the mind well distracted."

"Distracted," said Charles Ridgeway thoughtfully.

Charles was a thoughtful young man. He was also a young man who believed in furthering his own inclinations whenever possible.

That evening he suggested the installation of a radio set.

Here Dr. Meynell makes a prognosis about how long Charles' aunt is likely to live. Mrs Harder, his aunt, has a certain cardiac weakness; therefore, she must lead a very quiet life, and avoid worry and excitement. The echoic mentioning of the modifier 'distracted' evokes the implicature that is directly opposite to the intended one, in which the speaker tacitly dissociates himself from an attributed utterance or thought [17]. The echoic mentioning is reinforced through anadiplosis (thoughtfully $\rightarrow$ a thoughtful young man $\rightarrow$ also a young man who ...), hooking the words and phrases together in developing the main idea of the story. The main idea of the story can be explained with the help of the well-known proverb "where there's a will, there's a way" for fulfilling it. It means that if you want to get something, first you should do something. So Charles suggests the installation of the radio set in the house, which imparts not only the comic, but also the tragic undertone to the whole story.

№ 5

"You don't want me, then?" he said, in his subtle, insinuating voice.

"I don't want to speak to you," she said, averting her face.

"You put your hand on me, though," he said. "You shouldn't have done that, and then I should never have thought of it. You shouldn't have touched me."

"If you were anything decent, you'd know that was a mistake, and forget it," she said.

In the story, in a household full of women, the father is determined to replace his own male presence with someone of his own choosing, his fostered son Hadrian. Hadrian "shan't forget" Matilda's touch even though he knew "it was a mistake", whereas Matilda was more biased and resisted the marriage. In response, Hadrian keeps blaming Matilda for igniting the fire. He wants what he thinks is owed to him, for she is merely a woman in a man's world. Here the echoic mentioning of the blame serves to ensure the echoic meaning and evaluation intended by the author.

№ 6

"What do you persecute me for, if it isn't for the money? I'm old enough to be your mother. In a way I've been your mother."

"Doesn't matter," he said. "You've been no mother to me. Let us marry and go out to Canada - you might as well - you've touched me."

She was white and trembling. Suddenly she flushed with anger.

"It's so indecent," she said.
"How?" he retorted. "You touched me."

Due to the variance of educational background, social environment, and personality, Matilda and Hadrian have their distinct standards of living, social sense, and emotion. Matilda has a different mind and living objectives though she is obliged to interact with, and even to marry Hadrian. As in the previous fragment of conversation, the structure is sustained throughout the work by echoic mentioning of the blame Hadrian is laying on Matilda.

№ 7

Suddenly he drew in his breath. She had poured the tea into the three bowls. One she set before him, one before herself, the other she placed on a little table by the fire near the chair her husband usually sat in, and it was as she placed this last one on the table that a little strange smile curved round her lips. It was the smile that did it.

\section{He knew!}

A remarkable woman - a dangerous woman. No waiting - no preparation. This afternoon - this very afternoon - with him here as witness. The boldness of it took his breath away.

The retired police inspector Mr Evans suspects that Mrs Merrowdene, former Mrs Anthony, wants to poison her husband. Therefore, he is convinced that he needs to stop a murder from happening. His mixed emotions of admiration and astonishment are reflected through the use of emphatic structures in free indirect speech. On the whole, free indirect speech conveys the author's sarcasm about his professional deformation [19]: he is hunting for Mrs Merrowdene; whereas, in fact, he is the intended target himself. As it turned out, he dies after being poisoned in her house.

№ 8

Mr Hopkinson coughed. A dry cough.

"You have had no - er - disagreement with your aunt, Mr Ridgeway?" he murmured.

Charles gasped.

"No, indeed," he cried warmly. "We were on the kindliest, most affectionate terms, right up to the end."

“Ah!” said Mr. Hopkins, not looking at him.

It came to Charles with a shock that the lawyer did not believe him....

But it wasn't so! Charles knew one of the bitterest moments of his career. His lies had been believed. Now that he spoke the truth, belief was withheld. The irony of it!

In the story, Charles uses a rigged radio to produce a voice from the dead and frighten to death his wealthy aunt. His aunt's unexpected death arouses the lawyer's suspicions. Therefore, when Charles claims that he was on good terms with his aunt, the lawyer does not believe him. The lawyer's distrust arouses his bitter emotions conveyed through the use of emphatic structures in free indirect speech. The conflict of interests is reinforced through antithesis (litotes vs overstatement) aimed at emphasizing contrasting emotions: distrust vs sincerity, creating the ironic effect, as a result. 


\section{№ 9}

The telephone rang sharply at his elbow. He took up the receiver. It was the doctor's voice, hearty and kindly.

"That you, Ridgeway? Thought you'd like to know. The autopsy's just concluded. Cause of death as I surmised. But as a matter of fact the cardiac trouble was much more serious than I suspected when she was alive. With the utmost care she couldn't have lived longer than two months at the outside. Thought you'd like to know. Might console you more or less."

"Excuse me," said Charles, "would you mind saying that again?"

"She couldn't have lived longer than two months," said the doctor in a slightly louder tone. "All things work out for the best, you know, my dear fellow-"

But Charles had slammed back the receiver on its hook....

Damn them all! The smug-faced lawyer. That poisonous old ass Meynell. No hope in front of him only the shadow of the prison wall.

In the story, the accidental destruction of his aunt's will deprives Charles of the money. Moreover, the doctor's prognosis was erroneous: his aunt's state of health was not as good as it was diagnosed. Therefore, Charles' disappointment is doubled when he learns that if he had waited a few months, she would have died of natural causes, and he would have had the money without having committed murder. His disappointment and anger are reflected through the use of emphatic structures in free indirect speech.

Now we shall analyse examples of structural irony with the fallible narrator, and the naïve hero who serve to sustain a duplex meaning and evaluation throughout the work [20]. In structural irony, the first-person narrator/the hero is speaking sincerely, communicating what he or she believes to be the truth:

№ 10

'Here's another thing I always carry. A souvenir of Oxford days. It was taken in Trinity Quad - the man on my left is now the Earl of Doncaster.'

It was a photograph of half a dozen young men in blazers loafing in an archway through which were visible a host of spires. There was Gatsby, looking a little, not much, younger - with a cricket bat in his hand.

Then it was all true. I saw the skins of tigers flaming in his palace on the Grand Canal; I saw him opening a chest of rubies to ease, with their crimsonlighted depths, the gnawing of his broken heart.

In the novel, Nick serves as a first-person unreliable narrator who makes an incorrect assumption in the belief that Gatsby is from a well-to-do family. He identifies Gatsby on the photo, and reinforces his identification through the use of understatement and anaphora, thus confirming his naïve belief that Gatsby was from their lot. This pattern of behavior - confirmation - is repeated throughout the novel.

\section{№ 11}

'I told you I went there,' said Gatsby.

'I heard you, but I'd like to know when.'
'It was in nineteen-nineteen, I only stayed five months. That's why I can't really call myself an Oxford man.'

Tom glanced around to see if we mirrored his unbelief. But we were all looking at Gatsby.

'It was an opportunity they gave to some of the officers after the armistice,' he continued. 'We could go to any of the universities in England or France.'

I wanted to get up and slap him on the back. I had one of those renewals of complete faith in him that I'd experienced before.

The repetition of Gatsby's past experiences and ensuing Nick's renewal of complete faith in him creates the effect of irony felt by the readers, thereby bonding them with the writer.

№ 12

"Wonder what he does in there," he would murmur. "Looks like he'd just stick his head out the door."

Jem said, "He goes out, all right, when it's pitch dark. Miss Stephanie Crawford said she woke up in the middle of the night one time and saw him looking straight through the window at her ... said his head was like a skull lookin' at her..."

"Wonder what he looks like?" said Dill.

Here the narrator is a naïve hero Scout. She and her brother Jem become friends with a boy called Dill, who has come to live in their neighborhood for the summer, and the trio act out stories about the Radleys. Because Scout is seeing the situation from inexperienced eyes, she does not fully understand what is happening. She as the narrator says things (e.g. using similes) that reflect her utter ignorance of the situation, and are clearly in opposition to the author's true beliefs. As a reader, with more experience, we recognize the gap between the children's naïve outlook informed by fairy tales, and certain events that are happening in the story. By reinforcing the distance, the author raises the issue of generation gap, as a result.

№ 13

"Let's try to make him come out," said Dill. "I'd like to see what he looks like."

Jem said if Dill wanted to get himself killed, all he had to do was go up and knock on the front door.

Here Jem is warning Dill sincerely about the consequences of his actions. The irony therefore has to be inferred by the reader, who sees the flaws in his presentation of reality (e.g. in using overstatement), and perceives the author's true underlying attitude. The recurrent pattern of behavior is reinforced through the use of emphatic structure in free indirect speech, creating the humorous effect.

№ 14

"What about coming back and sitting down?" Duncan asked.

"Can't do it." He was glad for an excuse. As always, he felt Lorraine's passionate, provocative attraction, but his own rhythm was different now.

"Well, how about dinner?" she asked. 
"I'm not free. Give me your address and let me call you."

In this situation, Charlie after a long break again comes to Paris for his daughter with the firm intention to set up a family. He is settled now with an apartment in Prague. He is sober now, only one drink a day; he is lonely now, no one to hold or love or help him through the loneliness. He wants his daughter back from the people who have legal rights to her, his sister-in-law and her husband. However, his former companions in all likelihood specifically pursue him to have a drink at his expense. This pattern of behavior - suggestion of a drink - is repeated throughout the story.

№ 15

With a perceptible shrug of her shoulders, Lorraine turned back to Charlie:

"Come and dine. Sure your cousins won' mine. See you so sel'om. Or solemn."

"I can't," said Charlie sharply. "You two have dinner and I'll phone you."

Her voice became suddenly unpleasant. "All right, we'll go. But I remember once when you hammered on my door at four A.M. I was enough of a good sport to give you a drink. Come on, Dunc."

Still in slow motion, with blurred, angry faces, with uncertain feet, they retired along the corridor.

"Good night," Charlie said.

"Good night!” responded Lorraine emphatically.

Before leaving, Charlie visits the family of his sisterin-law, in which his daughter was brought up. However, his friends suddenly come after him to his sister-in-law's apartment to invite him to a restaurant. Charlie's refusal aroused Lorraine's indignation, reproaching him for his ingratitude. The irony of events is that the past is entrapping him, and he has to pay for his wrong doing in his youth. As a result, his sister-in-law refuses to entrust him with the care of a daughter, and he comes back to Prague alone.

Thus, in contradistinction to other ironies, structural irony applies to a work overall, typically through a naïve hero or unreliable narrator, whose view of the world differs widely from the true circumstances recognized by the author or the readers. Structural irony is built into literary discourse in such a way that both the surface meaning and deeper implications are present more or less throughout. It serves to create the conflict of interests as the driving force of the development of the plot. Unlike in verbal irony, where the speaker is intentionally ironic, the narrator/the hero in structural irony is speaking sincerely, communicating what he or she believes to be the truth, but the effect achieved is ironic.

The distance between the author and narrator/the hero can be referred to as "structural irony". The use of free indirect speech becomes significant in this respect: it creates a distancing effect and positions the hero further away from the reader. In the paper, we considered such pragmalinguistic techniques of constructing structural irony as the play on double meaning, the echoic mentioning of the word or phrase, the use of emphatic structures in free indirect speech, and repetition of patterns of behavior, which are employed in tandem. As the analysis of the material shows, the most frequent device for creating structural irony is repetition of patterns of behavior.

\section{References}

1. S. Hamilton, Essential literary terms: A brief Norton Guide with exercises, 2nd ed. ( WW Norton \& Co, New York, 2016)

2. L. Elleström, Divine madness: on interpreting literature, music, and the visual arts ironically (Bucknell University Press, Lewisburg, PA, 2002)

3. J. Nelson, Film Reader, 2 (1977) - Cited by: R. H. Brown, Society as text: essays on rhetoric, reason, and reality (University of Chicago Press, Chicago, 1987)

4. D. H. Green, Irony in the medieval romance (Cambridge University Press, Cambridge, [Eng.] ; New York, 1979)

5. L. Olsen, Colby Library Quarterly 19, 4, December, 215-220 (1983)

6. L. R. Furst,. Romantic irony and narrative stance, Romantic Irony, F. Garber, Ed. (Akadémiai Kiadó, Budapest, 293-309, 1988)

7. W. C. Booth, A rhetoric of irony (The University of Chicago Press, Chicago, 1974)

8. D. C. Muecke, Irony and the ironic, The critical idiom Series 13 (Metheuen and Co., New York, 1970)

9. L. Hutcheon, Irony's edge: the theory and politics of irony (Routledge, London and New York, 1994)

10. D.C. Muecke, The compass of irony (Methuen, London, 1969)

11. S.I. Pokhodnya, Language means of expressing irony in English-language prose (on the material of English and American fiction at the end of the XIX$X X$ centuries): dis. ... cand. philol. sciences. Kiev, 1984

12. M. Yu. Orlov, Text-forming irony in Russian and English-language prose: dis. ... cand. philol. sciences. Saratov, 2005

13. O.G. Petrova, Proc. Saratov State University, Ser. Phil. Journ. 11, 3. 25-30 (2011)

A. Christie, Accident, English story (PH Manager, M., 105-17, 2000)

14. D. Lawrence, The lovely lady, English story (PH Manager, M., 168-94, 2000)

A. Christie, Where there's a will, Selected Detective Stories (PH Manager, M., 233-53, 2000)

15. D. Wilson, Lingua 116, 1722-43 (2006)

16. D. Lawrence, You touched me, English story (PH Manager, M., 143-67, 2000)

17. Déformation professionnelle in WikipediA. Retrieved from "https://en.wikipedia.org/w/index.php?title=Déform 
ation_professionnelle\&oldid=82998024"9 ( date of access: 10.05.18)

18. M. H. Abrams, A Glossary of literary terms. 7th edition (Heinle \& Heinle, Boston, 1999)

19. F. S. Fitzgerald., The great Gatsby (PH Manager, M., 2000)

20. H. Lee, To kill a mockingbird (PH Anthology, SPb, 2014)

21. F. S. Fitzgerald, Babylon revisited, American story (PH Manager, M., 93-125, 1999) 